\title{
A rare case of Ludwig's angina after viper bite
}

\author{
Yeow Hoay Koh
}

Department of Neurology, National Neuroscience Institute of Singapore, Singapore General Hospital, Singapore, Singapore

\section{Correspondence to Dr Yeow Hoay Koh, kohyeowhoay@gmail.com}

Accepted 17 May 2017

\section{DESCRIPTION}

A previously healthy 20 -year-old woman presented to our Accident and Emergency Department of Degehbur Hospital, a small district hospital in Somali region of Ethiopia, with complaints of rapidly progressive swelling in her neck and difficulty in swallowing for the past 2 days (figures 1 and 2). She was bitten by a snake, which was later identified as a viper, over her right lower jaw while sleeping on the floor. She did not seek any medical treatment until day 3 when the swelling became worse and involved both submandibular region and the tongue. She also complained of rapidly increase shortness of breath for the past 24 hours.

On arrival at the accident and emergency department, she had noisy breathing, drooling of saliva and difficulty in closing her mouth. There was diffuse swelling over both of her submandibular regions and tongue. It was swollen, tender and inflamed. On examination, she was febrile with temperature of $39.5^{\circ} \mathrm{C}$. Her pulse rate was 120 / $\mathrm{min}$ and respiratory rate $30 / \mathrm{min}$. Inspiratory stridor was present. Pulse oximeter was not available in the hospital but she was not cyanosed. Complete blood count showed markedly raised white blood cells $19.6 \times 10^{9} / \mathrm{L}$, predominantly neutrophils $(90 \%)$.

Clinical diagnosis of Ludwig's angina was made. She was immediately given $6 \mathrm{mg}$ of intravenous dexamethasone, $1 \mathrm{~g}$ of ceftriaxone, $500 \mathrm{mg}$ of metronidazole, intravenous hydration and oxygen. No antivenom was given as it was not available. Her

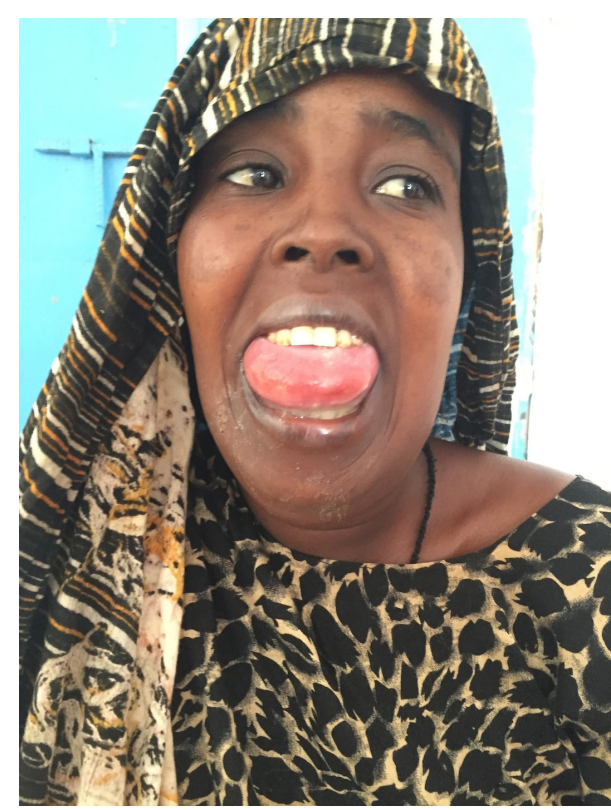

Figure 1 The patient presented to emergency department with severe swelling of her tongue, neck and submandibular area.

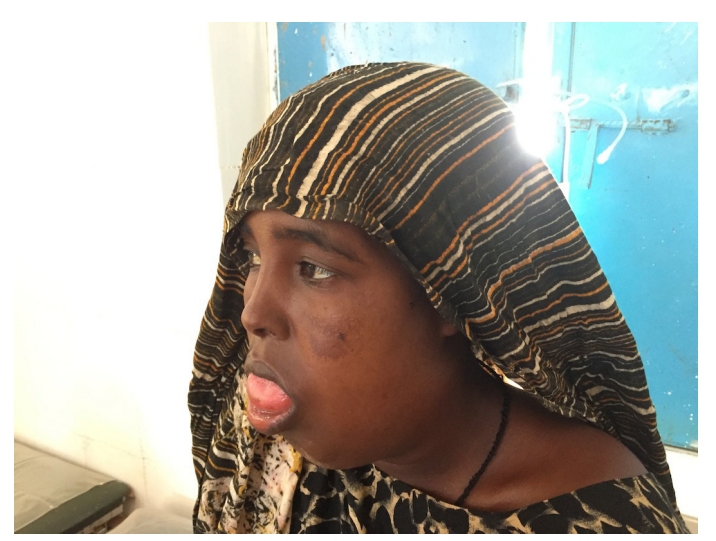

Figure 2 Lateral view of the patient showing severe submandibular swelling that obscuring the airway.

condition remained the same 30 min after administration of medications. She was advised to be referred to a nearby hospital as tracheostomy, intensive care unit (ICU) and surgical service were not available in Degehbur Hospital. She was managed conservatively as she declined for any surgical intervention or tracheostomy, and the nearest hospital with ICU and surgical service was 4 hours drive away from Degehbur.

During her hospital stay, she responded well with intravenous antibiotics and dexamethasone. The swelling and respiratory distress subsided after 10 days of intravenous antibiotics and 5 days of intravenous dexamethasone. She was discharged 10 days later.

The complication of snakebite can be local or systemic. Viperidae, colubridae and crotalidae families are commonly associated with local complication, such as cellulitis, necrosis or fasciitis. ${ }^{1}$ Furthermore, contamination from oral flora of the snake could cause secondary wound infection. In this case, local effect from the viper envenoming and secondary infection would cause severe soft tissue inflammation and swelling of the neck, tongue and submandibular area, and later on it would progress to Ludwig's angina.

Ludwig angina was first described by Karl Friedrich Wilhelm von Ludwig in 1836, as a rapidly and frequently fatal progressive gangrenous cellulitis and oedema of the soft tissues of the neck and floor of the mouth. ${ }^{2}$ It is exceptionally rare nowadays as a result of widely available antibiotics therapy and advances in medical and surgical care. Majority of the cases are caused by untreated odontogenic infections (90\%), while other aetiologies include peritonsillar abscess, peripharyngeal abscess, sialadenitis, neoplasm, tongue piercing or neck trauma. ${ }^{3}$

Airway compromise is the leading cause of death in Ludwig's angina. Mortality rate of Ludwig's 


\section{Learning points}

- Ludwig's angina is a potentially life-threatening cellulitis of the floor of the mouth, which may lead to rapid airway compromise and death.

- Clinical signs of severely compromised airway include respiratory rate $>25$ breaths/min, oxygen saturation on room air $<95 \%$, and significant airway compromise on fibre-optic laryngoscope.

- Although no specific guideline for airway management in Ludwig's angina at present, patients with difficult airway (defined as condition in which a trained anaesthesiologist has difficulty with face mask ventilation of the upper airway or tracheal intubation) should be intubated by assisted fibreoptic bronchoscope or surgical tracheostomy.

angina without proper airway management is $>50 \%$ for Ludwig's angina. ${ }^{4}$ Clinical signs of severely compromised airway include respiratory rate $>25$ breaths/min, oxygen saturation on room air $<95 \%$ and significant airway compromise on fibre-optic laryngoscope. In this condition, a definitive airway is required. There is no specific guideline regarding airway management in Ludwig's angina at present. However, 'Practice Guidelines for Management of the Difficult Airway' from American Society of Anaesthesiologists recommend that patients with difficult airway (defined as condition in which a trained anaesthesiologist has difficulty with face mask ventilation of the upper airway or tracheal intubation) should be intubated by assisted fibre-optic bronchoscope or surgical tracheostomy. ${ }^{2}$

Ideally, this case should be sent for airway management, by either intubation or tracheostomy, and ICU care. However, the benefit of surgical intervention and airway support needs to be weighed against the risk of further airway deterioration during the transfer as the nearest hospital with ICU care is 4 hours drive away.

Contributors YHK is the only author contributed to the work presented in this paper.

Competing interests None declared.

Patient consent Obtained.

Provenance and peer review Not commissioned; externally peer reviewed.

(C) BMJ Publishing Group Ltd (unless otherwise stated in the text of the article) 2017. All rights reserved. No commercial use is permitted unless otherwise expressly granted.

\section{REFERENCES}

1 Nelson BK. Snake envenomation, incidence, clinical presentation and management. Med Toxicol Adverse Drug Exp 1989;4:17-31.

2 Caplan RA, Benumof JL, Berry FA, et al. "An updated report by the American Society of Anesthesiologists Task Force on management of the difficult airway," Anesthesiology 2003;98:1269-77.

3 Quinn FB. Ludwig angina. Arch Otolaryngol Head Neck Surg 1999;125:599.

4 Saifeldeen K, Evans R. Ludwig's angina. Emerg Med J 2004;21:242-3.

Copyright 2017 BMJ Publishing Group. All rights reserved. For permission to reuse any of this content visit http://group.bmj.com/group/rights-licensing/permissions.

BMJ Case Report Fellows may re-use this article for personal use and teaching without any further permission.

Become a Fellow of BMJ Case Reports today and you can:

- Submit as many cases as you like

- Enjoy fast sympathetic peer review and rapid publication of accepted articles

- Access all the published articles

- Re-use any of the published material for personal use and teaching without further permission

For information on Institutional Fellowships contact consortiasales@bmjgroup.com

Visit casereports.bmj.com for more articles like this and to become a Fellow 